\title{
KEY ISSUES IN ADULT NON FORMAL PARTICIPATORY E-LEARNING
}

\author{
Gilberto Marzano \\ Rezekne Technology Academy, Latvia \\ Velta Lubkina \\ Rezekne Technology Academy, Latvia \\ Luis Ochoa Siguencia
}

The Jerzy Kukuczka Academy of Physical Education in Katowice, Poland

\begin{abstract}
This paper is concerned with participatory learning, and focuses on the issues that can arise in the application of participatory approaches in e-learning-based adult non-formal education programmes. It analyses the assumptions on which participatory learning theories lie, and discusses the current portability of participatory adult learning practices to an online environment. Some key issues in adult non-formal participatory e-learning will be presented, taking into account the available literature and the first results of ESCAlADE, an $E U$ funded project started at the end of 2015, which focuses on adult non-formal participatory learning.

Keywords: adult education, e-learning, participatory adult e-learning, design of e-learning participatory programmes.
\end{abstract}

\section{Introduction}

The World Health Organisation (WHO) estimates that the number of older adults (aged 65 years and over) will be approaching 1.5 billion by 2050 (2011 estimate). The demographics of the world are at a turning point: we are moving ever more into an era of ageing population, and this circumstance is already impacting the cost of social security systems. In many European countries, the increasing cost of retirement benefits is being dealt with by moving people's retirement age back in relation to their life expectancy. The most obvious consequence of this is that more people will have to work until later in life. At the same time, advances in technology are bringing continuous change to every aspect of society, including the professional sphere and, consequently, the world of work is in a permanent state of flux. Thus the necessity to both work later in life and learn new skills many times until retirement are becoming critical aspects of the workers' situation today.

Lifelong learning is generally seen as a means to address the issues of preserving employability, while flexible learning is invoked by insiders as a 
solution to the profound transformations of contemporary society. Adult education, especially for the low-skilled, is deemed more and more strategic since it can help to meet the needs for new skills, and ensure that an ageing workforce remains productive. Moreover, lifelong learning can be important tools to provide for people's social inclusion and active citizenship: topical issues in view of the wave of refugees and immigrants currently arriving in European countries.

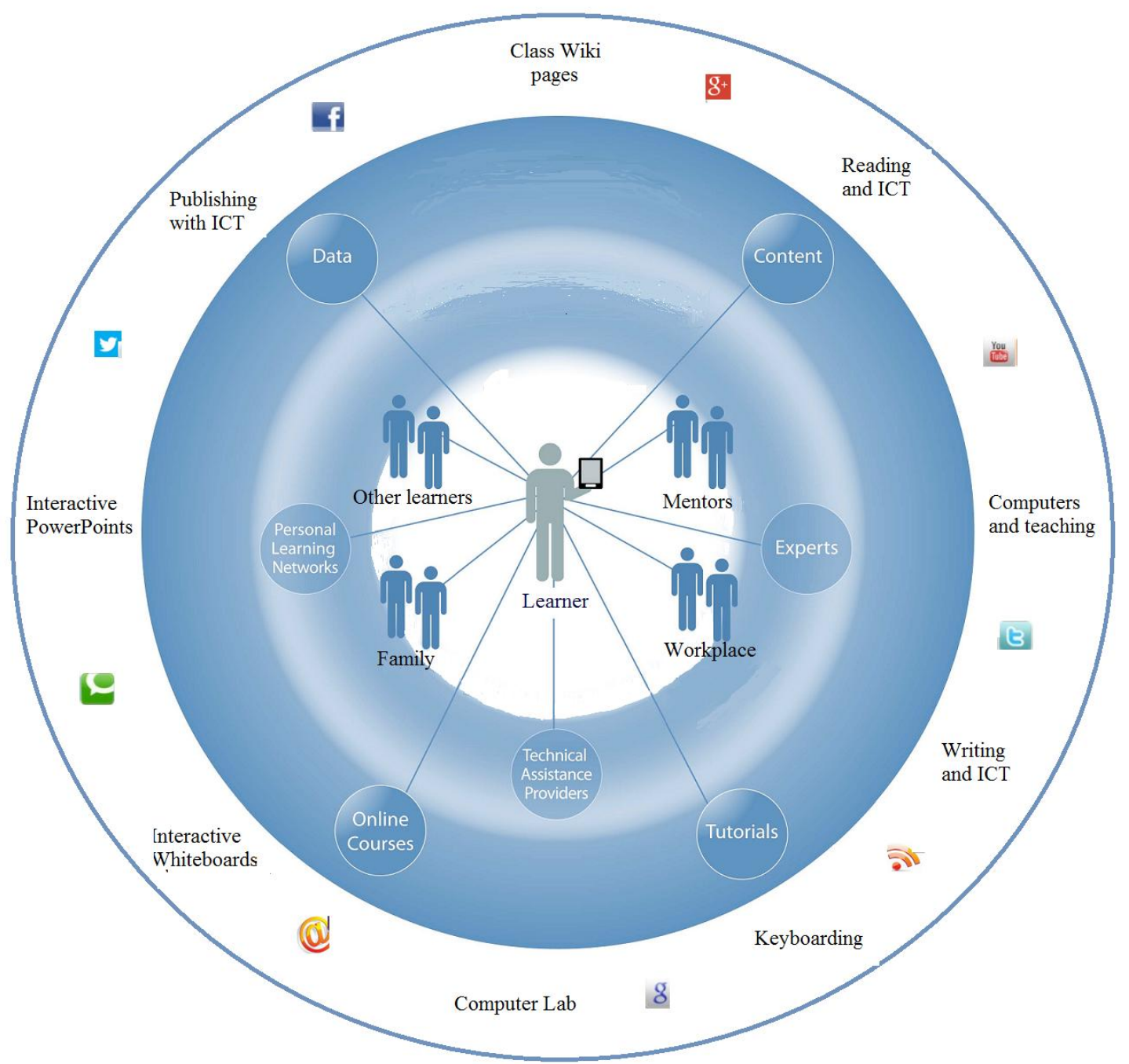

Figure 1 Integration of participatory practices into an on-line learning environment

The Education and Training 2020 (ET 2020) programme ${ }^{1}$, the new strategic framework for European cooperation in education and training, underlines that these days people can no longer rely on the skills they acquired at school for their entire working lives. On the technology side, the literature emphasises the

\footnotetext{
${ }^{1}$ https://www.consilium.europa.eu/uedocs/cms_data/docs/pressdata/en/educ/107622.pdf: last accessed 18.02.2016.
} 
relevance of Web 2.0 applications, arguing that they have created a new participatory mindset in which users are not simple consumers of information, but have themselves become producers of web content. Over the last few years, many researchers have begun to investigate how the expanding new forms of Web interaction can be exploited in adult non-formal education, in order to facilitate and enhance learning capability.

This paper is concerned with the integration of participatory practices into an on-line learning environment (see figure 1). It focuses on the issues that may arise with the application of participatory approaches in adult on-line learning programmes. Various assumptions made by participatory learning theories have been analysed, and the current portability of participatory adult learning practices to an on-line environment is discussed.

Opportunities and barriers are illustrated, taking into account the available literature on participatory adult learning.

\section{Participatory adult learning}

Participatory learning is grounded in John Dewey's idea that students achieve better results if the learning process "reproduces, or runs parallel to, some form of work carried on in social life". 2 On a philosophical level, participatory learning can be seen as the natural consequence of two Deweyan concepts: that learning is a problem solving process, and that there isn't any dualism between the subject matter and the method (Dupuis \& Gordon, 2010).

Participatory learning represents a family of approaches, methods, attitudes, behaviours, and relationships that have their theoretical basis in behaviourism as well as in constructivism (Rodrigues, 2014). Constructivist theories of learning argue that knowledge is constructed by learners who better learn by actively applying their know-how to meaningful problems (Brown \& Palincsar, 1989).

Participatory learning methods comprise a wide range of activities, which share a student-centred view aimed at enabling learners to play an active and influential part in their learning process. This means that learners are not merely listened to, but also actively collaborate to acquire knowledge and skills: in other words, participatory learning focuses on student participation.

In the 1990s, participation was a popular buzzword, and the concept of participation was also extended into the field of education. Participatory learning was often experimented to support sustainable development, above all in regards to the agriculture of developing countries (Coldevin, 2002), as well as a means

\footnotetext{
${ }^{2}$ p. 92 in: Dewey, J. (auth.), \& Boydston, J. A. (Ed.) (1983). The middle works, 1899-1924 (Vol. 13). SIU Press.
} 
to aid the democratic progress of emerging countries, since participatory learning is, by its very nature, collaborative and so directly fosters democracy. Certain adult participatory learning techniques are also very popular and widely used in management training (especially for project managers and supervisors), such as brainstorming, problem solving, project work, and critical incident response.

Participatory learning requires facilitators. These facilitators interact with learners, for example providing discussion subjects, presenting case studies, presenting tasks that call for participants to work together in small groups, and so on. These types of exercises are aimed at the active involvement of all learners in the learning process, stimulating them to think through their mindset and share with others their experience and knowledge, as well as their values and beliefs. Although facilitators and coaches have many overlapping skills and functions, their role is different: a coach provides individual attention and addresses personal development with an emphasis on a specific task, whereas a facilitator provides a group with meaningful dialogue and broadens personal perspectives, encouraging the entire group to participate collectively so as to increase their ability to operate effectively on their own.

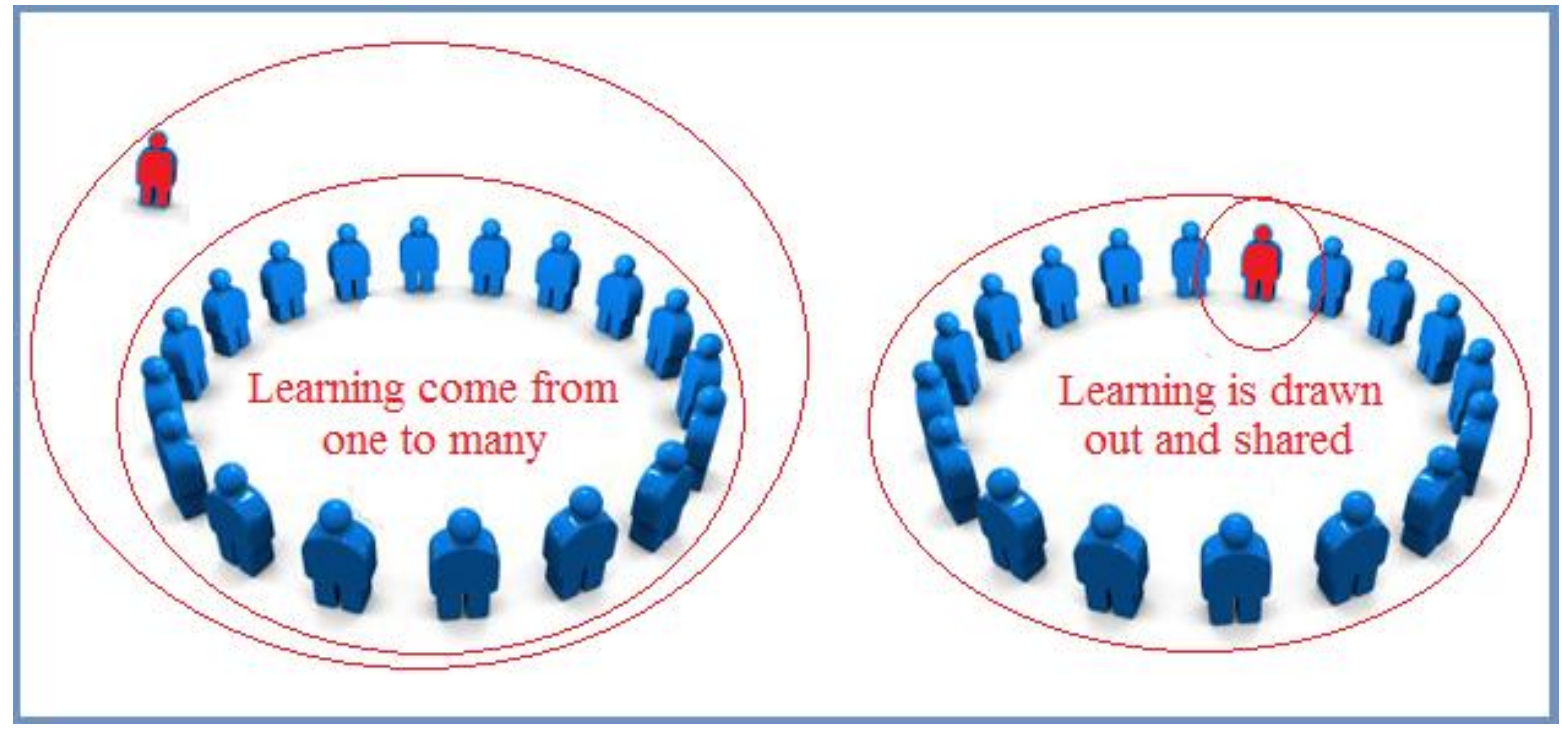

Figure 2 The main difference between learning and e-learning

\section{Participatory Adult Learning Strategy (PALS)}

The Participatory Adult Learning Strategy (PALS) is an evidence-based approach to adult participatory learning developed by Dust and Trivette, which results from over 20 years of research and practice and, more recently, from the findings of the meta-analyses of adult learning methods and the synthesis of 
research studies into the most effective adult learning practices (Trivette Dunst, Hamby \& O'herin, 2009; Dunst \& Trivette, 2009; Dunst, Trivette \& Hamby, 2010).

PALS authors analysed and measured the positive affect of four adult learning methods: accelerated learning (Meier, 2000), coaching (Hargreaves \& Dawe, 1990), guided design (Hancock, Coscarelli \& White, 1983), and just-intime training (Beckett, 2000). From their research, the relative importance of active learner participation in learning new knowledge or practices emerged, and from this result a procedure was designed for using evidence-based practices in adult learning.

The PALS model encompasses a 4-phase process that includes:

1. Introduction - the learning topic and related information is preliminarily provided to learners, as well as in-class/workshop warmup exercises and illustrations/demonstrations.

2. Application - trainees apply information learned; the instructor/facilitator observes their activity, giving feedback and evaluating their use of knowledge.

3. Informed Understanding - trainees are engaged in self-assessment, reflection, and group discussions.

4. Repeat Learning Process - the next steps in the learning process are planned in order to provide further learner understanding, knowledge use, and mastery.

The PALS model, as the result of an empirical analysis of best practice in adult education, is obviously consistent with the most effective adult learning approaches. However a question arises: how do participatory practices work in an on-line learning environment? This question is a part of a more general issue that concerns the portability of participatory approaches and techniques to online web-based learning contexts.

At present, rethinking and evolving the vast legacy of traditional training courses appears to be a crucial exercise since educators emphasise the advantages of training opportunities via distance education, arguing that modern digital technology and Web 2.0 tools can revitalise learning.

Synchronous distance learning sessions involving virtual classrooms equipped with e-whiteboards have passed the experimental phase, while asynchronous learning sessions and Web 2.0 tools (podcasts, wikis, chat, forum, blogs) and a virtual world environment (namely OpenSim) are widely used. Meanwhile new forms of informal learning at a lower cost, such as learning through blogs (Downes, 2004; Farmer \& Bartlett-Bragg, 2005), and through podcasts and videocasts (Ractham \& Zhang, 2006), have attracted the interest of researchers, and are now spreading. 
To understand the current portability of participatory approaches to an online learning environment it would be useful to turn to the 4-phase PALS model, after noting some key factors that influence adult participatory e-learning.

\section{Adult non-formal participatory e-learning}

The literature on adult non-formal participatory e-learning shows that there is a broad consensus of opinion concerning the positive correlation between a learner's personal satisfaction and the achievement of their educational objectives (Kidd, 2009). Moreover, many researchers share the opinion that adult e-learning courses that are developed without a careful analysis of the needs of the students are doomed to failure. In fact, adult learners represent a multi-faceted category that is also sensitive to the socio-economic situation.

Regarding participatory e-learning, there are some assumptions that are generally agreed on. One of these is that the success of participatory e-learning depends on the interaction of learners, since they are bringers of knowledge and skills (Kok, 2015).

Another important aspect is that active learning is fundamental for participatory e-learning (see figure 3): learners are involved in practices that require actively constructing new knowledge and understanding.

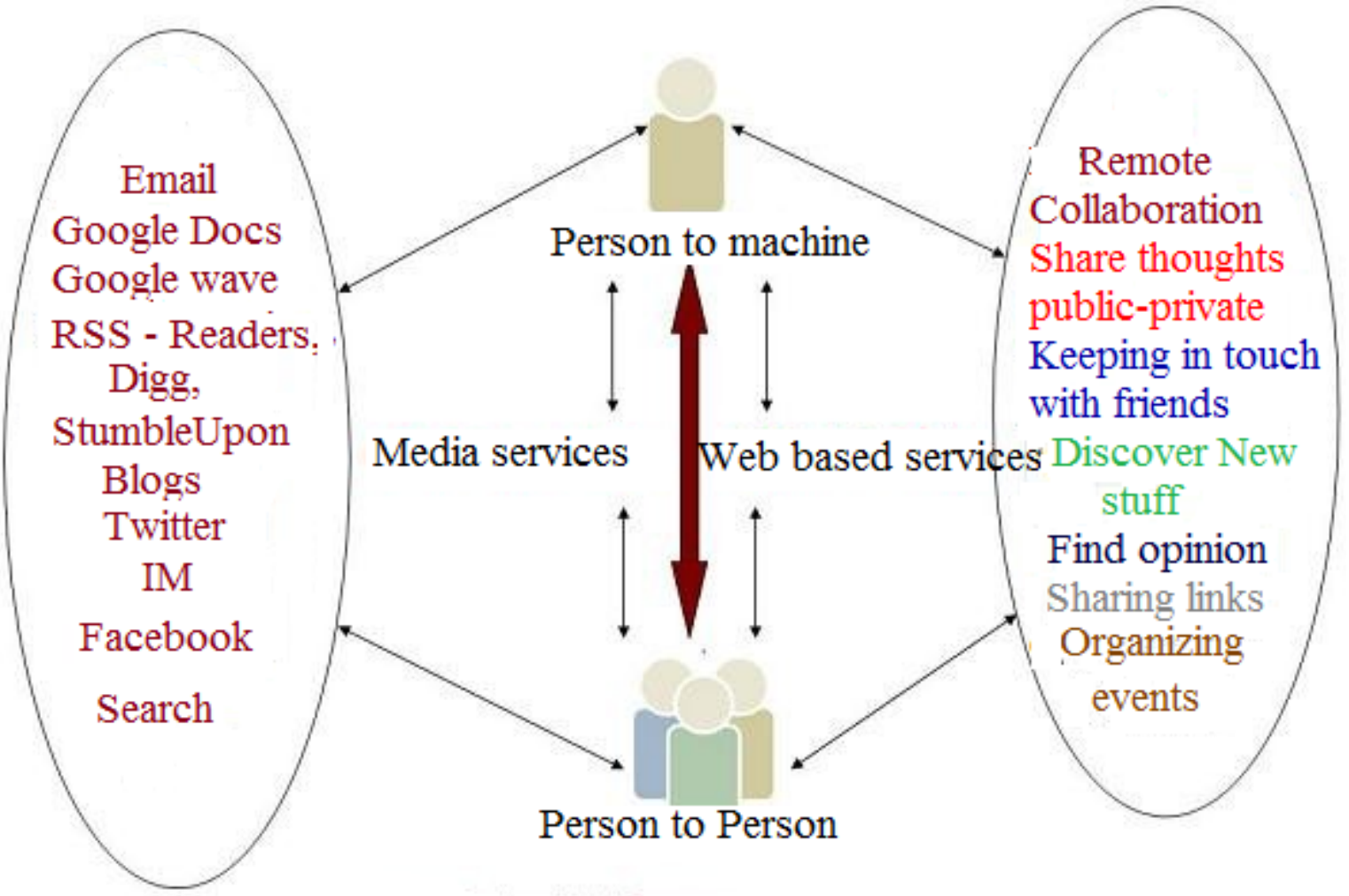

Figure 3 Active learning in the EScAIADE project 
Many e-learning systems offer collaborative functions that allow cooperation and facilitate communication among learners, teachers, mentors, tutors, and administrators. These collaborative functions result from the Web 2.0 revolution that in the last few years has swept away the old paradigm of digital communication. ${ }^{3}$ Web 2.0 encompasses a variety of websites and applications that allow anyone to create and share online information and materials they have created. The key difference between Web 2.0 and the traditional types of websites is that it does not require any web design or publishing skills to create and publish materials on the Web.

There are a variety of Web 2.0 applications including wikis, blogs, social networking, folksonomies, podcasting, and so on. Many of the most popular websites are Web 2.0 sites, such as Wikipedia, YouTube, Facebook, MySpace, and Instagram.

The Web 2.0 revolution has also influenced the educational field with $e$ learning 2.0 that has expanded the concept of the learning community, focusing on supporting the development and solving educational problems through online collaboration. ${ }^{4}$

The principal aims of e-learning Web 2.0 are:

- to make learning collaborative, easy, and simple;

- $\quad$ to allow learning materials to be used on a global level;

- to allow a real interactivity between teachers and learners, and among learners;

- to encourage developing practices, with the sharing of educational content and teaching methods.

At the moment, despite its topicality, the portability of adult learning participatory approaches to an on-line environment represents a challenging issue, as demonstrated by the scarce experimental data that is available on this subject. However, from the first outcomes of a research conducted within EScAlADE, ${ }^{5}$ it is quite evident that e-learning Web 2.0 applications do not necessarily cover all the 4-phases of the PALS model. Some reflections that have emerged from the EScAlADE ongoing research are reported below.

\footnotetext{
${ }^{3}$ The term „Web 2.0" was first coined in January 1999 by Darcy Di Nucci, an expert in information architecture, but has been in popular use since 2004 when O'Reilly Media and MediaLive hosted the first Web 2.0 conference in San Francisco.

4 The debate over what is a learning community is still open since learning occurs in a variety of settings.

${ }^{5}$ EScAlADE is an EU funded project, started at the end of 2015, that focuses on adult non-formal participatory learning, and involves partners from five European countries (Italy, Latvia, Poland, Greece, and Spain).
} 


\section{Some issues in adult non-formal participatory e-learning}

It has been observed that e-learning 2.0 is based on synchronous and asynchronous Web 2.0 tools, mixing classical e-learning tools with the social services of Web 2.0 (Greenhow, Robelia \& Hughes, 2009). For this reason, despite e-learning Web 2.0 applications offering a wide range of collaborative tools - many of them derived from groupware software - the implementation and delivery of effective participatory e-learning courses is not easy, especially for adults. Much of the effectiveness of participatory e-learning depends on the educational context (teachers, facilitators, learners, available resources) and on the level of integration of e-learning tools and social services.

From an analysis of the current literature, two main problems appear in relation to adult participatory e-learning. Firstly, there are different learning styles and characteristics in the field of adult learning (Caffarella \& Barnett, 1994; Merriam, Caffarella \& Baumgartner, 2012) and not all of these are portable to a participatory e-learning environment. Secondly, the digital divide, both cultural and physical, can represent a barrier and reduce the applicability of participatory approaches in the e-learning environment.

Table 1 shows the e-tools that are usable within the 4 phases of the PALS model; of course their effectiveness depends on the context.

Table 1 PALS model and electronic tools

\begin{tabular}{|c|c|c|c|}
\hline Phase & Tool & Communication & Note \\
\hline Introduction & $\begin{array}{l}\text { Classical e-learning } \\
\text { tools }\end{array}$ & Asynchronous & \\
\hline Application & $\begin{array}{l}\text { Classical e-learning } \\
\text { tools, social Web } 2.0 \\
\text { services (e.g. chat, on- } \\
\text { line forum, Skype, } \\
\text { video conference, etc.), } \\
\text { work cooperative tools } \\
\text { (word processor, } \\
\text { spreadsheet, shared } \\
\text { agenda, etc.) }\end{array}$ & $\begin{array}{l}\text { Synchronous and } \\
\text { asynchronous }\end{array}$ & $\begin{array}{l}\text { Need to plan } \\
\text { participatory activities } \\
\text { between teachers and } \\
\text { learners and among } \\
\text { learners }\end{array}$ \\
\hline $\begin{array}{l}\text { Informed } \\
\text { Understanding }\end{array}$ & $\begin{array}{l}\text { Classical Web services } \\
\text { and virtual forums }\end{array}$ & Asynchronous & $\begin{array}{l}\text { Use of electronic form, } \\
\text { self-evaluation tests }\end{array}$ \\
\hline $\begin{array}{l}\text { Repeat Learning } \\
\text { Process (mastery) }\end{array}$ & $\begin{array}{l}\text { Classical Web services } \\
\text { (planner, word } \\
\text { processor, shared } \\
\text { agenda, etc.) }\end{array}$ & Asynchronous & \\
\hline
\end{tabular}

In adult participatory e-learning some variable aspects play an important role in addition to course climate, personal interest and motivation, career 
aspiration, etc. Adult participatory e-learning is also affected by technological factors such as skill levels in new technologies, the availability of hardware and software, and the reliability of internet connection. Another important element is the different ways in which teachers and facilitators interact with learners. This entails the design of customisable applications. Finally, an important question concerns the cost. Participatory learning requires the presence of facilitators, and this increases the cost of courses designed with a participatory approach. The cost evaluation of participatory e-learning is not easy. Participatory learning in an on-line environment is still a novelty, and experimental analysis is required in order to identify effective elements that can be used for evaluating its costs.

\section{Conclusion}

Web 2.0 has introduced a new participatory mindset: users are not merely consumers of information, but have become producers of content.

At the same time, adult learners who are fully engaged in learning activities with their peers appear to be more likely to participate effectively in other educational practices, and are generally more positive about the educational process.

They will become knowledge creators, produce work for a wider audience, employ both non-formal and informal learning, see that what they learn will serve them elsewhere and is transferable to other contexts, and develop a sense of a learning community.

It is well known that people remember more if they are actively involved in their own learning process. For this reason, expanding new forms of Web interactions in adult non-formal education can facilitate and enhance learning capability. However, one cannot take for granted the full portability of face-toface adult participatory learning approaches to an on-line environment.

Our opinion, which has developed from the ongoing research within the EScAlADE project, is that the participatory concept ought to be rethought in the light of the opportunities offered by the new technologies. This will lead to the design of new learning approaches that will most likely represent a hybrid combination of classical e-learning, Web 2.0 services, and face-to-face activities. We are persuaded that new technologies can enhance the mainstream learning in adult education, but to develop an effective learning model it is necessary to collect experiences and conduct experiments. This is what the EScAlADE project is intended to do. On the basis of the analysis of data obtained from a transnational survey, we will prepare a participatory experiment with a sample group of adult learners. The experiment will be designed taking the PALS model into account, and will be aimed at obtaining evidence of the portability of participatory approaches to an on-line learning environment. 
Gilberto Marzano, Velta Lubkina, Luis Ochoa Siguencia. Key Issues in Adult Non Formal

Participatory E-Learning

\section{Acknowledgments}

This paper was supported by the European project EScAlADE ("Education Strategies adult education"). The views expressed in this paper reflect those of the authors alone, and the European Commission cannot be held accountable for any use that may be made of the information contained herein.

\section{References}

Beckett, D. „Just-in-time training as anticipative action and as inferential understanding.” DOCUMENT RESUME (2000): 27. http://files.eric.ed.gov/fulltext/ED451388.pdf\# page $=28$; last accessed 19.01.2016.

Brown, A. L., \& Palincsar, A. S. (1989). Guided, cooperative learning and individual knowledge acquisition. Knowing, learning, and instruction: Essays in honour of Robert Glaser, pp. 393-451.

Caffarella, R. S., \& Barnett, B. G. (1994). Characteristics of adult learners and foundations of experiential learning. New directions for adult and continuing education, 1994 (62), pp. $29-42$.

Coldevin, G. (2002). Participatory Communication and Adult Learning for Rural Development: Three Decades of FAO Experience. Servaes, J. (2002). (Ed.), Approaches to Development Communication, pp. 44-75.

Downes, S. (2004). Educational blogging. Educause review, 39 (5), pp. 14-26.

Dunst, C. J., \& Trivette, C. M. (2009). Let's Be PALS: An Evidence-Based Approach to Professional Development. Infants \& Young Children, 22 (3), pp. 164-176.

Dunst, C. J., Trivette, C. M., \& Hamby, D. W. (2010). Meta-analysis of the effectiveness of four adult learning methods and strategies. International Journal of Continuing Education and Lifelong Learning, 3 (1), pp. 91-112.

Dupuis, A. M., \& Gordon, R. L. (2010). Philosophy of education in historical perspective. University Press of America.

Farmer, J., \& Bartlett-Bragg, A. (2005, December). Blogs@ anywhere: High fidelity online communication. In ASCILITE (Vol. 5, pp. 4-7).

Gough, D. A., Kiwan, D., \& Sutcliffe, K. (2003). A Systematic Map and Synthesis Review of the Effectiveness of Personal Development Planning for Improving Student Learning. London: EPPI-Centre, Social Science Research Unit.

Greenhow, C., Robelia, B., \& Hughes, J. E. (2009). Learning, teaching, and scholarship in a digital age Web 2.0 and classroom research: What path should we take now? Educational researcher, 38 (4), pp. 246-259.

Hancock, B. W., Coscarelli, W. C., \& White, G. P. (1983). Critical thinking and content acquisition using a modified guided design process for large course sections. Educational \& Psychological Research.

Hargreaves, A., \& Dawe, R. (1990). Paths of professional development: Contrived collegiality, collaborative culture, and the case of peer coaching. Teaching and teacher education, 6 (3), pp. 227-241.

Kidd, T. T. (Ed.). (2009). Online Education and Adult Learning: New Frontiers for Teaching Practices: New Frontiers for Teaching Practices. IGI Global.

Kok, A. (2015). Integration of Web 2.0 Tools in to Non-formal Learning Practices: A Case Study of IBM. Procedia-Social and Behavioral Sciences, pp. 176 \& 357-370. 
Meier, D. (2000). Accelerated Learning Handbook: A Creative Guide to Designing and Delivering Faster. McGraw-Hill.

Merriam, S. B., Caffarella, R. S., \& Baumgartner, L. M. (2012). Learning in adulthood: A comprehensive guide. John Wiley \& Sons.

Moir, J. (2009). Personal Development Planning in Higher Education: Localised Thinking for a Globalised World. In: Resende, J. M., Vieira, M. M. (Eds.) The Crisis of Schooling? Learning, Knowledge and Competencies in Modern Societies (pp. 25-48). Newcastle upon Tyne: Cambridge Scholars Press.

Montagnes, I. (2001). Textbooks \& learning materials 1990-1999: a global survey. http://unesdoc.unesco.org/images/0012/001234/123487e.pdf; last accessed 19.01.2016.

Petty, G. (2004). Teaching Today. UK: Nelson Thornes Ltd.

Ractham, P., \& Zhang, X. (2006, April). Podcasting in academia: a new knowledge management paradigm within academic settings. In Proceedings of the 2006 ACM SIGMIS CPR conference on computer personnel research: Forty-four years of computer personnel research: achievements, challenges \& the future (pp. 314-317). ACM.

Rodrigues, S. (Ed.). (2014). Handbook for teacher educators: transfer, translate, or transform. Springer.

Thorson, J. A., \& Powell, F. C. (1993). Development and Validation of a Multidimensional Sense of Humor Scale. Journal of Clinical Psychology, 49, pp. 13-23.

Trivette, C. M., Dunst, C. J., Hamby, D. W., \& O'herin, C. E. (2009). Characteristics and consequences of adult learning methods and strategies. Winterberry research syntheses, 2 (2), pp. 1-33.

World Health Organisation. (2011). Global health and ageing. http://www.who.int/ ageing/publications/global_health.pdf; last accessed 18.01.2016. 